\title{
Major Changes in the Ecology of the Wadden Sea: Human Impacts, Ecosystem Engineering and Sediment Dynamics
}

\author{
Britas Klemens Eriksson, ${ }^{1 *}$ Tjisse van der Heide, ${ }^{2}$ Johan van de Koppel, ${ }^{3}$ \\ Theunis Piersma, ${ }^{4,5}$ Henk W. van der Veer, ${ }^{5}$ and Han Olff ${ }^{2}$
}

\begin{abstract}
${ }^{1}$ Department of Marine Benthic Ecology and Evolution, Centre for Ecological and Evolutionary Sciences, University of Groningen, Groningen, The Netherlands; ${ }^{2}$ Community \& Conservation Ecology, Centre for Ecological and Evolutionary Sciences, University of Groningen, Groningen, The Netherlands; ${ }^{3}$ Department of Spatial Ecology, Netherlands Institute of Ecology (NIOO), Yerseke, The Netherlands; ${ }^{4}$ Animal Ecology Group, Center for Ecological and Evolutionary Sciences, University of Groningen, Groningen, The

Netherlands; ${ }^{5}$ Department of Marine Ecology, Royal Netherlands Institute for Sea Research (NIOZ), Texel, The Netherlands
\end{abstract}

\begin{abstract}
Shallow soft-sediment systems are mostly dominated by species that, by strongly affecting sediment dynamics, modify their local environment. Such ecosystem engineering species can have either sediment-stabilizing or sediment-destabilizing effects on tidal flats. They interplay with abiotic forcing conditions (wind, tide, nutrient inputs) in driving the community structure and generating spatial heterogeneity, determining the composition of different communities of associated species, and thereby affecting the channelling of energy through different compartments in the food web. This suggests that, depending on local species composition, tidal flats may have conspicuously different geomorphology and biological functions under similar external conditions. Here we use a historical reconstruction of benthic production in the Wadden Sea to construct a framework for the relationships between human impacts, ecosystem
\end{abstract}

engineering and sediment dynamics. We propose that increased sediment disturbances by human exploitation interfere with biological controls of sediment dynamics, and thereby have shifted the dominant compartments of both primary and secondary production in the Wadden Sea, transforming the intertidal from an internally regulated and spatially heterogeneous, to an externally regulated and spatially homogenous system. This framework contributes to the general understanding of the interaction between biological and environmental control of ecosystem functioning, and suggests a general framework for predicting effects of human impacts on soft-bottom ecosystems.

Key words: bivalves; deposit feeders; internal regulation; human transformation; soft sediment food-webs; historic trends.
Received 11 February 2010; accepted 28 May 2010; published online 30 June 2010

Author Contributions: Britas Klemens Eriksson have written the text and compiled the data. All other authors have actively participated in formulating the hypotheses and compiling the manuscript.

*Corresponding author; e-mail: b.d.h.k.eriksson@rug.nl

\section{INTRODUCTION}

Across the world, human dominated coastal ecosystems are losing populations and species at an accelerating rate, with a strong risk of permanent impairment to key ecosystem functions and 
recovery potential (Lotze and others 2006; Worm and others 2006). Coastal soft-sediment systems comprise intertidal flats and estuaries which are highly productive, usually with a strong tradition of human exploitation (Costanza and others 1997; Lotze and others 2006; Airoldi and Beck 2007). The Wadden Sea is such a shallow estuarine area bordering the North Sea. In the course of intensified urbanization of coastal habitats, intertidal areas in Europe have been subjected to a dramatic degradation of food-web complexity and ecosystem services by multiple stressors. These include: pollution with nutrients and chemicals, the development of increasingly intense forms of exploitation (for example, shellfish dredging, bottom trawling), natural habitat destruction through large-scale hydraulic engineering (for example, diking and reclamation), which not only acts locally but also changes hydrodynamic conditions and increases suspended sediment concentrations over large areas (Wolff 2000; Cloern 2001; Lotze and others 2005; Wolff 2005; Lotze and others 2006; Airoldi and Beck 2007). Although many studies have shown that ecosystem engineers, such as reef forming bivalves and seagrasses, fulfil key-functions in structuring intertidal soft-bottom ecosystems (Verwey 1952; Reise 1985; Bouma and others 2009 and references therein) there is an ongoing debate on their relevance as independent and significant drivers of change in the Dutch part of the Wadden Sea (the western part). Current integrative analyses of causes of ecological change in the the Dutch Wadden Sea have emphasized processes acting on primary producers (temperature, nutrient inputs) much more than changes in top-down processes resulting from exploitation of higher trophic levels (for example, Weijerman and others 2005; Philippart and others 2007). Here we argue that failure to detect and document clear consequences of the intense human exploitation of multiple trophic levels in the western Wadden Sea mainly result from poor recognition of the importance of non-linear dynamics caused by the biological feedbacks that characterize benthic softsediment systems (Verwey 1952).

In marine ecosystems at large, the tightly integrated relationship between trophic structure and ecosystem processes for maintaining ecosystem functioning is widely acknowledged (Menge 2000; Worm and others 2002; Daskalov and others 2007; Österblom and others 2007). Interactions between top-down and bottom-up regulation have been demonstrated in a wide variety of systems and scales, and consensus is now emerging on the importance of considering the joint effects of fisheries and eutrophication in management of marine resources (Österblom and others 2007; Eriksson and others 2009). However, soft-sediment ecosystems are also controlled by strong non-trophic interactions from the critical feedbacks that many soft-sediment organisms have on the environmental conditions that in turn affect their own and other organism's performance ('ecosystem engineers'; sensu Jones and others 1994; Bouma and others 2009; Olff and others 2009).

Species that dominate the shallow benthos of soft-sediment systems have a high impact on environmental conditions related to sediment properties, such as sediment stability, texture, aeration, resuspension and sedimentation (Hall 1994; Schaffner and others 2001; Montserrat and others 2008; Bouma and others 2009; Van Colen and others 2009). These species include seagrasses, biogenic reefs of suspension feeding bivalves and a number of bioturbating polychaete worms and crustaceans, all of which not only respond to sediment stability and texture but also strongly affect it (Reise 1985; Flach 1992; van de Koppel and others 2005a; Huxham and others 2006, van der Heide and others 2007). Altering local sediment dynamics by either increasing the erosion of the sediment or promoting the settlement of finer particles causes these species to be a major force on regional landscape-forming processes, interacting with the hydrodynamics imposed upon the system by waves and currents (Bouma and others 2009).

Due to the prevalence of ecosystem engineering, effects of human exploitation may have highly persistent implications for soft-bottom communities. Modelling studies from both marine and limnic soft-sediment communities with strong feedbacks between dominating species groups and the environment suggest that distinctly different communities structured by different processes may develop under similar external conditions (Scheffer and others 2001; Rietkerk and others 2004; van de Koppel and others 2005a). This suggests that tidal flats may have conspicuously different geomorphology and biological functions largely depending on the local dominance of species. Furthermore, human impacts on soft-sediment systems commonly have direct effects on sediment conditions (for example, Piersma and others 2001; Erftemeijer and Lewis 2006). Thus, exploitation of specific benthic fauna together with disruption of the sediment dynamics may result in a highly resistant modification of the biological community by deleting the biological feedback mechanisms that determine the sedimentary environment ('hysteresis'). Here we use available historic estimations 
and time-series data on nutrients, light, primary production (PP) and abundances of ecosystem engineers from the western part of the Dutch Wadden Sea to construct a conceptual framework on the ways in which human impacts may have caused fundamental changes in soft-sediment ecosystems. We propose that human impacts have modified coastal production and caused non-linear effects on community structure by increasing sediment disturbance, and thereby have changed the Wadden Sea from an internally to an externally regulated ecosystem.

\section{Trends in Primary Producers}

Historically, there were three dominant compartments of PP in the Wadden Sea: phytoplankton, subtidal seagrasses (Zostera marina L.) and benthic microalgae (Wolff and others 1979). Seagrasses are generally limited by light availability, which is determined by wave action and the load of suspended sediment (Hemminga and Duarte 2000, de Boer 2007). In addition, seagrass meadows stabilize sediment conditions by slowing water flow, physically binding the sediment and increasing the deposition of fine sediments, which depending on the strength of the environmental drivers may significantly increase water clarity (Ward and others 1984; Terrados and Duarte 2000). Thus, by reducing turbidity seagrasses may create an important positive feedback, which in some ecosystems promotes distinct alternative and stable states at similar environmental conditions: one with high abundances of subtidal seagrass and low turbidity, and one with little subtidal seagrass and high turbidity (Gunderson 2001; de Boer 2007). Common human activities in soft-bottom systems such as bottom trawling, dredging and sand suppletion for coastal defence, all resuspend the sediment and thereby increase turbidity (Peterson and others 1987; Churchill 1989; Langton and Robinson 1990; Riemann and Hoffmann 1991; Shepherd and Boates 1999). Accordingly, there are numerous reports of large-scale losses of seagrass related to degenerated light conditions in the water caused by dredging (Erftemeijer and Lewis 2006) and/or increased plankton biomass from nutrient enrichment (Cloern 2001; Burkholder and others 2007). This has caused seagrass meadows to currently be among the most endangered marine habitats (Duarte 2002; Orth and others 2006). In contrast, benthic microalgae also photosynthesize during low tide, and should therefore not be as affected by water transparency. Here we propose that increased sediment disturbance may shift the dominant compartments of PP in benthic soft-bottom communities by negative effects primarily on sediment stabilizing seagrass with a long turnover time (Figure 1A). We also suggest that this trend is accentuated by nutrient enrichment, which promotes fast-growing ephemeral micro- and macroalgae over perennial macrophytes (Cloern 2001).
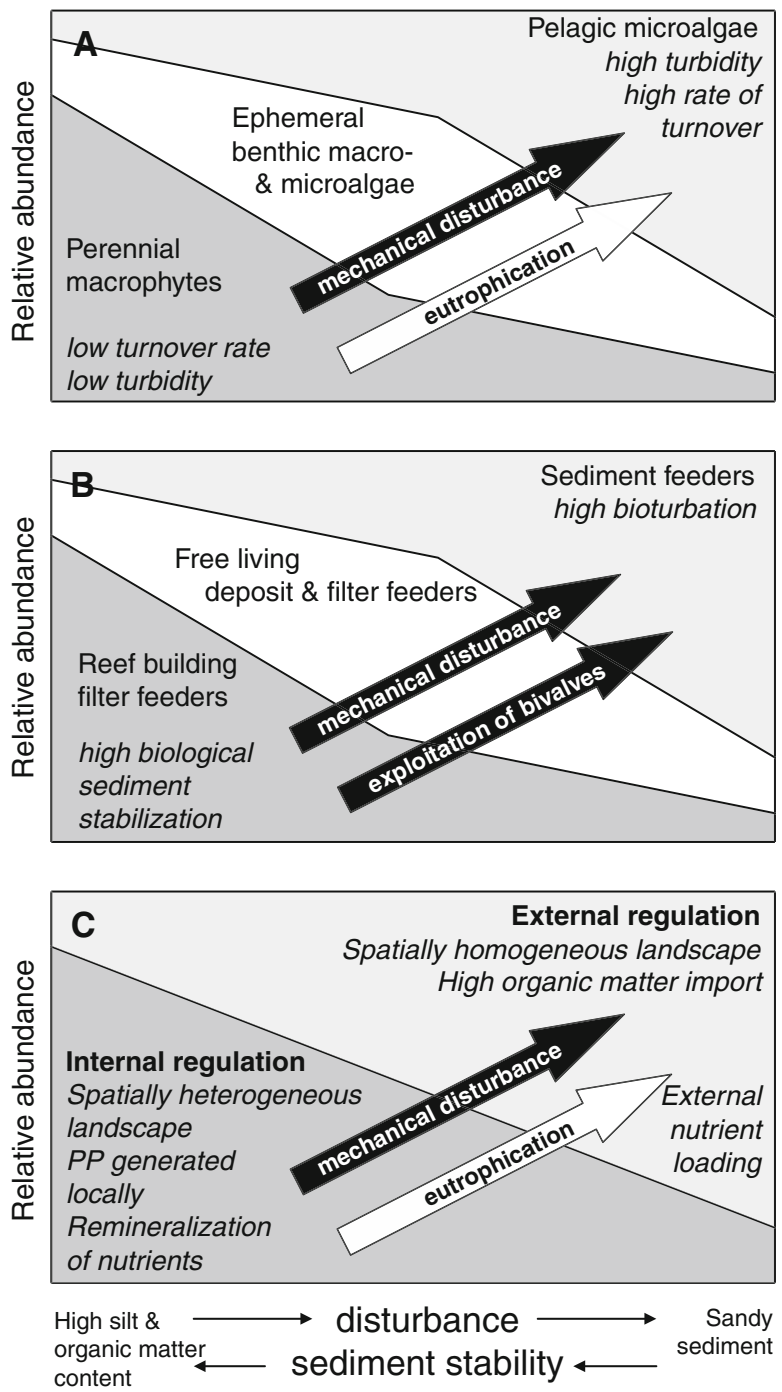

Figure 1. Proposed relation between sediment stability, human disturbances and community structure/drivers in soft sediment ecosystems. A composition of primary producers, B composition of benthic fauna, and $\mathbf{C}$ the relation between external and internal ecosystem drivers. Arrows show effects of human activities: Black arrows activities that directly influence the relation between dominating communities and sediment properties. Mechanical disturbances include effects on the sediment by dredging and trawling. Bivalve exploitation indicates direct removal of bivalves. White arrows nutrient enrichment. 
The historical development of dominant compartments of PP and abiotic factors in the Dutch Wadden Sea show distinct phases related to major events when human activities intensified in the past century (Figure 2A, B). The first intensification of human impacts, a large scale sediment disturbance event, correlates with massive decreases in subtidal seagrass cover, and from then on increased relative importance of microalgae for total PP in the Wadden Sea. From 1927 to 1932 a damming project closed off an area of $1100 \mathrm{~km}^{2}$ (formerly known as the Zuiderzee) from the rest of what is now known as the Dutch Wadden Sea. Dredging and gulley rearrangement lowered light conditions in the water by increasing the concentration of suspended particles, which together with the arrival of the wasting disease wiped out almost the whole subtidal community of seagrass (Wolff and others 1979; Giesen and others 1990). We calculate a total loss of approximately 8200 ha sublittoral Zostera marina from the present part of western Wadden Sea in the early 1930s (Figure 2B; van der Heide and others 2007). Wolff and others (1979) estimated the total PP in the western Wadden Sea in 1970 to be $40 \%$ of the production in 1930 , where $47 \%$ of the total decline depended on a decrease in pelagic production from lower light transparency (from 158 to $59 \mathrm{gC} \mathrm{m}^{-2} \mathrm{y}^{-1}$ contribution calculated as average production per square $m$ related to the total area of the western Wadden Sea) and $12 \%$ of the decrease in benthic production due to loss of sublittoral seagrass (contribution down from $18-20$ to $0.04 \mathrm{gC} \mathrm{m}^{-2} \mathrm{y}^{-1}$ ). At the same time, the microphytobenthos was estimated not to have changed significantly (contribution both in 1930 and $1970,46.2 \mathrm{gC} \mathrm{m}^{-2} \mathrm{y}^{-1}$ ), increasing the relative contribution of benthic microalgae to total PP from 20 to $45 \%$. Van Beusekom (2005) estimated a much lower pre-historic pelagic production based on riverine nitrogen loading alone $\left(55 \mathrm{gC} \mathrm{m}^{-2} \mathrm{y}^{-1}\right)$. However, Wolff and others (1979) argued that the pelagic production in the Wadden Sea was light and not nutrient limited, and also described a nutrient rich Wadden Sea in the 1970s that had a comparably low PP limited by water transparency. Colijn and Cadee (2003) confirmed that transparency of the water was the most limiting factor for pelagic production in the western Dutch Wadden Sea in the 1990s. Pre-1930 densities of seagrass in the western Wadden Sea probably decreased resuspension of sediment more than 7 -fold (from $180.6 \mathrm{mg} / \mathrm{l}$ to $25.5 \mathrm{mg} / \mathrm{l}$ ) and reduced light attenuation 5.5-fold (from 6.8 to $1.2 \mathrm{~m}^{-1}$ ) above the beds (van der Heide and others 2007). Accordingly, Secchi depth decreased by at least $1 \mathrm{~m}$ from 1930 to 1960 on the mudflats, indicating that after the construction of the dam, large scale loss of the sediment stabilizing function of the sublittoral seagrass community together with changed hydrodynamic conditions increased turbidity permanently, and disrupted both benthic and pelagic production (Figure 2B; van der Heide and others 2007).

The second important intensification of human impacts on PP was a large-scale eutrophication of the system in the 1970-1980s, where microalgal production at first was significantly stimulated by high loads of phosphorus from poor waste water treatment and agricultural runoff (De Jonge and others 1993) and then decreased again with declining nutrient loads from improved management of water quality (van Raaphorst and de Jonge 2004; Philippart and others 2007). Thus, in the 1970s increasing nutrient loads restore the pre1930 pelagic production, but subtidal seagrass did not recover and light availability continued to decrease (Figure 2A, B). Nutrient enrichment is often fatal to diversity of primary producers with strong effects on community composition (for example, Eriksson and others 2006), but we have no century-long data series on trends in the diversity of pelagic plankton. Nevertheless, during the period of eutrophication (1970-1990), smaller flagellates increased the most (Philippart and others 2007). Later, when nutrient levels and pelagic production dropped back to pre-eutrophication levels, it was mainly larger diatoms that declined. Since 1995 the light levels in the water have continued to decrease and there is still no significant recovery of subtidal seagrasses in the Dutch Wadden Sea.

\section{Trends in Benthic Fauna}

Most of the species of the benthic fauna in the Wadden Sea have strong effects on sediment dynamics when they occur in high densities; ranging from the sediment-stabilizing bivalve reefs constructed by filter-feeding blue mussels (Mytilus edulis) and oysters (Ostrea edulis, Crassostrea gigas), and bank-forming cockles (Cerastoderma edule), to sandy fields dominated by the bioturbating, sediment-destabilizing lugworm (Arenicola marina). Like seagrasses, at high densities reef-building species decrease sediment erosion and facilitate finer particles to settle by slowing down water flow close to the bottom (Gutierrez and others 2003). This typically increases the organic content of the sediment surrounding intertidal mussel or oyster reefs. The recruitment of blue mussels and cockles on intertidal flats in the Wadden Sea correlates 

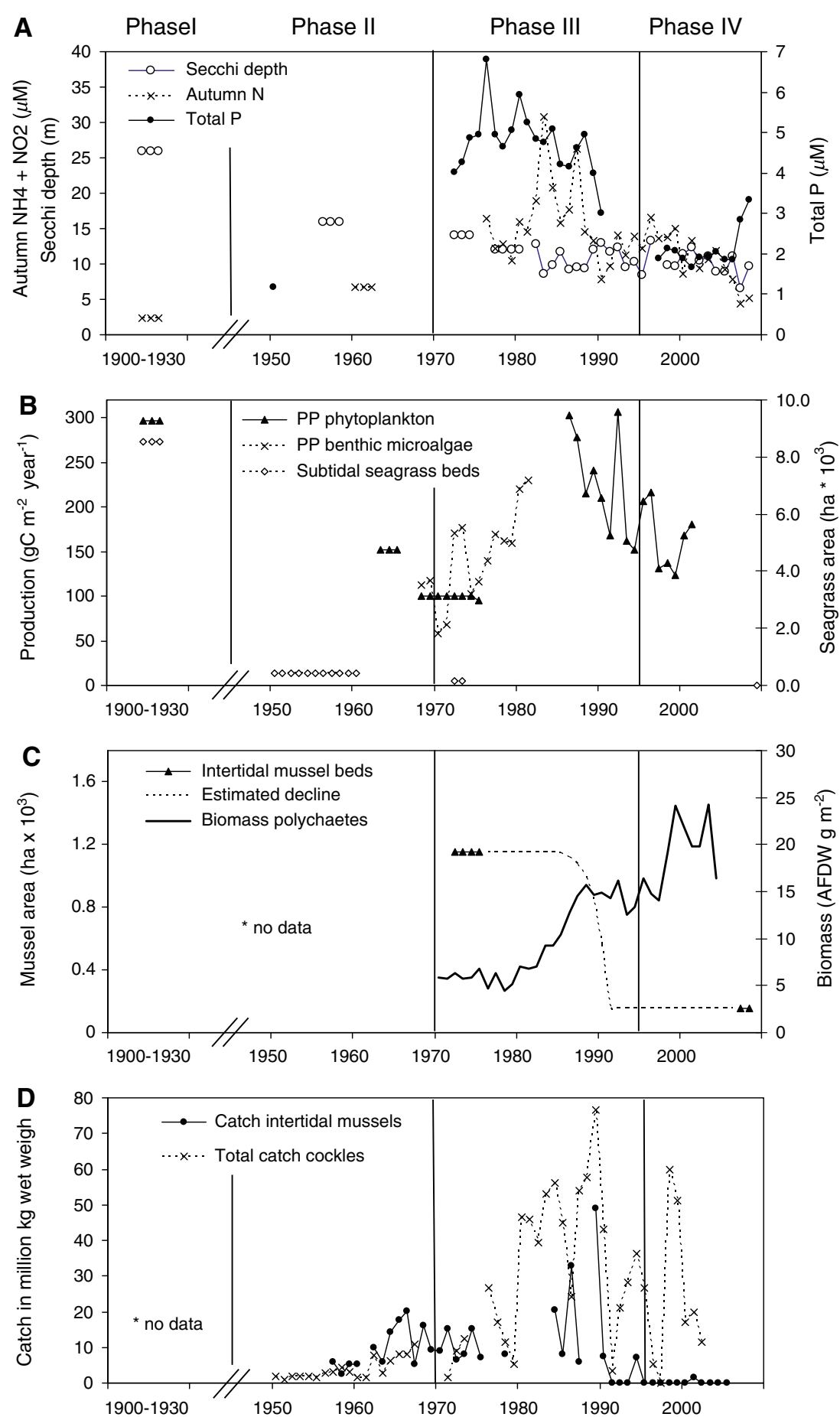

with relatively increased silt content of the sediment (Piersma and others 2001). This suggests that the engineering effect of bivalve reefs will promote their own recruitment and that there may be significant positive feedbacks between bivalves and sediment stability. Deposit feeding bioturbators (commonly polychaete worms or crustaceans) destabilize the sediment by digging or burrowing activities (Rhoads 1974). At high local densities, bioturbators may therefore disturb or preclude the sediment stabilizing feedbacks that increase the settling of finer particles, caused both by seagrass and mussel beds, and which promote the recruitment of many bivalves (Rhoads and Young 1970; Piersma and others 2001). Accordingly, there is evidence of mutually negative interactions be- 
4 Figure 2. Development of ecosystem function and human exploitation in the western Wadden Sea. A Environmental factors: open circles water clarity (Secchi depth), times nitrogen levels, and filled circles phosphorus concentrations. Historical water clarity (1930s, 19561958, 1970-1972 and 1977-1980) in the western Dutch Wadden Sea was determined by Giesen and others (1990). Loads of nitrogen (pre-industrial and 1960-1962) in the area were estimated by van Beusekom (2005). Concentrations of total phosphorus were reported by Postma (1954-station Marsdiep). Modern trends in nutrients and Secchi depths were compiled from the Dutch National Institute for Coastal and Marine Management, Rijkswaterstaat RIKZ (www.waterbase.nl), and subsets selected to be comparable to the historic estimations $\left(\mathrm{N}\right.$ conc. $=\mathrm{NH}_{4}+\mathrm{NO}_{2}$, annual means sept-nov, Doove Balg west; total $\mathrm{P}=$ annual means Marsdiep; Secchi depth, Doove Balg west). B Primary producers: filled triangles phytoplankton production, times benthic microalgal production, open diamonds subtidal seagrass meadows. Historic pelagic production (before 1932) was reconstructed by Wolff and others (1979). Pelagic PP after 1960 was compiled from data measured in the western Wadden Sea-Marsdiep (Cadee and Hegeman 1974; Philippart and Cadee 2000; Philippart and others 2007). Benthic microalgal production was quantified at Balgzand (Cadee 1980).The historical distribution of sublittoral seagrass (Zostera marina) was determined by van der Heide and others (2007). Later distribution information was compiled from Wolff and others (19501961 and 1973-74) and RIKZ (1994-2008; http:// www.rws.nl/water/natuur_en_milieu/zeegras). C Benthic fauna: filled triangles intertidal mussel beds, hatched line estimated decline (Beukema and Cadee 1996) and thick solid line polychaete biomass. Mussel bed distribution maps were taken from Governmental reports (19721975, 2007-2008). For polychaetes we retrieved biomass data from Balgzand (Essink 2005). D Human exploitation shown as total Dutch landings of intertidal mussels filled circles (Dankers and others 2003) and cockles times (Dijkema 1997; Kesteloo and others 2004).

tween seagrass and bioturbating polychaete worms (Philippart 1994; Hughes and others 2000) and crustaceans (Siebert and Branch 2006). For offshore systems, positive feedbacks between sediment conditions and the biological community have been suggested to cause distinct alternative communities dominated by either sediment-stabilizing brittle stars or bioturbating crustaceans at similar environmental conditions (van Nes and others 2007).

Throughout Europe, reef-building species declined dramatically over the last century through human exploitation of all sorts of bivalves, but especially oysters and mussel abundances have been severely affected (Lotze and Reise 2005; Lotze and others 2006; Airoldi and Beck 2007). In addi- tion to direct removal of bivalves, resuspension of the sediment connected to trawling and dredging destabilize sediment conditions and human activities may therefore also have indirect negative effects on bivalve recruitment. In the Wadden Sea, poor recruitment after a documented large-scale shellfish dredging event hindered reestablishment of blue mussels and cockles for almost a decade (Piersma and others 2001, and see reoccurring patterns documented by van Gils and others 2009). The poor recruitment coincided with changed sediment characteristics, where low sediment stability after the perturbation hindered sedimentation of finer silts and finer organic material which is associated with spatfall. Here, we propose that increased sediment disturbance by human exploitation of soft-sediment resources may disrupt sediment-stabilizing feedbacks, and thereby promote a shift from dominance of sediment-stabilizing filter feeders to dominance of sediment destabilizing bioturbating species (Figure 1B).

We have no historic estimates of the overall distribution of intertidal bivalve beds in the western Wadden Sea. However, fragmented blue mussel information suggests that the presence of blue mussel beds were at least as high before 1930 as in the 1970s, when they covered an total area of 1155 ha (Figure 2C; Dankers and others 2003). Starting in the 1980s, there was a strong increase of deposit/mixed feeding polychaetes that continued through the 1990s (at monitoring site Balgzand, Figure 2C; Essink 2005). Philippart and others (2007) showed that benthic secondary production increased significantly at this site comparing 19701980 with 1980-2000, due to a strong increase of deposit feeding macrozoobenthos. In the 1980s, fishing on intertidal resources also accelerated dramatically as demonstrated by a five and three times increase in the catch of cockles and mussels, respectively, compared with the decade before (Figure 2D, Dijkema 1997; Dankers and others 2003; Kesteloo and others 2004). In 1989-1990 the intertidal beds were completely removed in the western Dutch Wadden Sea and they did not recover (Beukema and Cadee 1996). Accordingly, the biomass of both blue mussels and cockles are low in the intertidal monitoring programs since the 1990s (Philippart and others 2007), whereas polychaetes have increased four times the biomass registered in the 1970s. In 2009, the intertidal area covered by mussel beds was 157 ha, 13\% of the area covered in the 1970s (Figure 2C). The shift from a high cover of sediment stabilizing bivalve beds to a high density of sediment-destabilizing lugworms is supported by a relative increase in worm eating bird 
species compared to bivalve feeding bird species in the Wadden Sea during this period (van Roomen and others 2005).

Blue mussel beds indirectly increase local PP (Asmus and Asmus 1991; Baird and others 2007). To estimate changes in the contribution of blue mussel beds to benthic PP in the intertidal, we related the changes in area of mussel beds in the western Dutch Wadden Sea to production data from the Sylt-Romö area in the north-eastern part of the Wadden Sea. The Sylt-Romö production data were collected during a 20 year period, compartmentalized into different habitat types and made available in Baird and others (2007). In the SyltRomö system, blue mussels are by far the most productive (1460 $\left.\mathrm{gC} \mathrm{m}^{-2} \mathrm{y}^{-1}\right)$ followed by dense Zostera noltii beds (intertidal seagrass: $368 \mathrm{gC} \mathrm{m}^{-2} \mathrm{y}^{-1}$ ). These two habitats are 6 and 1.5 times more productive compared to other benthic habitats (muddy and sandy flats and shoals: mean $=228$, $\mathrm{SE}=5 ; \quad$ Arenicola-flats: $\left.237 \mathrm{gC} \mathrm{m}^{-2} \mathrm{y}^{-1}\right)$. The strong increase in PP on mussel beds depends on perennial macroalgae which attach to the mussels, such as Fucus spp. The pelagic domain is by far the least productive $\left(90 \mathrm{gC} \mathrm{m}^{-2} \mathrm{y}^{-1}\right)$. According to these data, the documented decrease of blue mussels in the 1990s in the western Wadden Sea can be estimated as a loss in PP of $24 \mathrm{gC} \mathrm{m}^{-2} \mathrm{y}^{-1}$ averaged over the whole intertidal area (from a contribution of 28.0 to $3.8 \mathrm{gC} \mathrm{m}^{-2} \mathrm{y}^{-1}$ ).

Mussel beds also promote local pelagic production by remineralizing nutrients. Experiments from tidal pools show that the presence of mussels increases local PP up to eight times (Pfister 2007). Flume measurements over blue mussel beds in the field indicate that the potential pelagic production from release of nutrients significantly exceeds the reduction in phytoplankton by feeding (Asmus and Asmus 1991). For intertidal blue mussel beds in the northern Wadden Sea, $1 \mathrm{~m}^{2}$ of mussel bed sustains a pelagic production of $3.55 \mathrm{gC}$ per day in summer through nutrient release (corrected for phytoplankton uptake; Asmus and Asmus 1991). This indicates that the dramatic declines in bivalve reefs in the 1990s have decreased the production potential of the Wadden Sea significantly.

\section{INTERNAL Versus External Regulation}

The historic synthesis suggests that three major human impact events have contributed to changed drivers of ecosystem functioning in the Wadden Sea over the last century. This includes the dramatic loss of seagrass from dredging and disease in the 1930s, the major increase in production from eutrophication in the 1980s and the removal of all intertidal mussel beds and most of the high density cockle-beds in the 1990s. As shown, seagrass meadows and mussel banks provide conspicuous and large-scale internal regulation of ecosystem services, mainly by: (1) generating a heterogeneous landscape, both by their physical structures and by accumulating sediment (Gutierrez and others 2003; van der Heide and others 2007); (2) contributing much higher benthic primary and secondary production than other habitats on shallow soft-bottoms (Asmus and Asmus 2000; Baird and others 2007); and (3) promoting PP by improving the light climate (seagrass) and remineralization of nutrients (mussels) (Asmus and Asmus 1991; van der Heide and others 2007). Thus, a soft-sediment system dominated by sediment stabilizing ecosystem engineers is a system with a high degree of internal stimulation both of habitat heterogeneity and PP.

However, trophic dynamics of coastal systems are not only determined by local processes but also by the food web dynamics in deeper off-shore systems, and vice versa (Estes and others 1998; Jackson and others 2001; Ljunggren and others in press.). Globally, as well as for the Wadden Sea, off-shore food-webs have undergone massive changes over the last decades due to overexploitation of the main fish stocks (Wolff 2005; Worm and others 2006). Changes in off-shore food web configuration can cascade to coastal food-webs by changes in predation pressures (Jackson and others 2001) or as food-depletion caused by massive increases in migrating off-shore mesopredators (Ljunggren and others in press). Other dominating changes in external influences are an increased nutrient and organic matter load caused by a general eutrophication of major rivers (Vitousek and others 1997), and a predicted increase in storm frequency and wave intensity by climate change (Harley and others 2006). Intertidal mussel beds and oyster reefs may be severely eroded by extreme weather events, such as severe storms and accumulations of drift ice (Armonies and others 2001; pers. obs.). At the same time, changes in coastal ecosystem functioning in most soft-sediment systems by large scale loss of seagrasses, mangroves and/or reefs building species (Valiela and others 2001; Duarte 2002; Lotze and others 2006; Orth and others 2006) have probably lead to decreased nursery functions for the main off-shore crustacean and fish populations, thereby limiting the exchange of juveniles in many areas. Here we propose that by negative effects on sediment stabilizing ecosystem engineers through trawling and dredging, together with increased external inputs of nutrient resources, human 


\section{A historic situation}

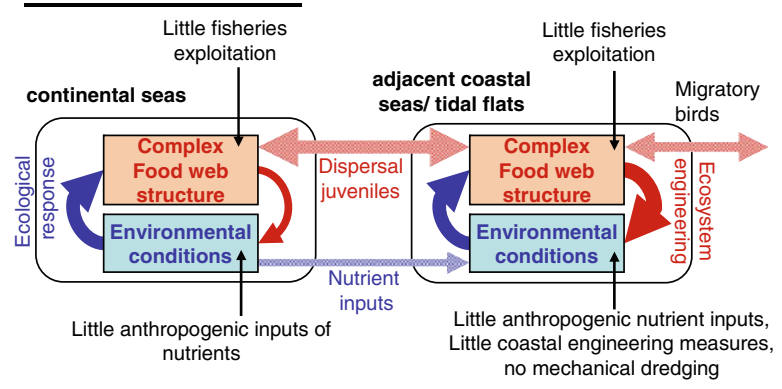

\section{B current situation}

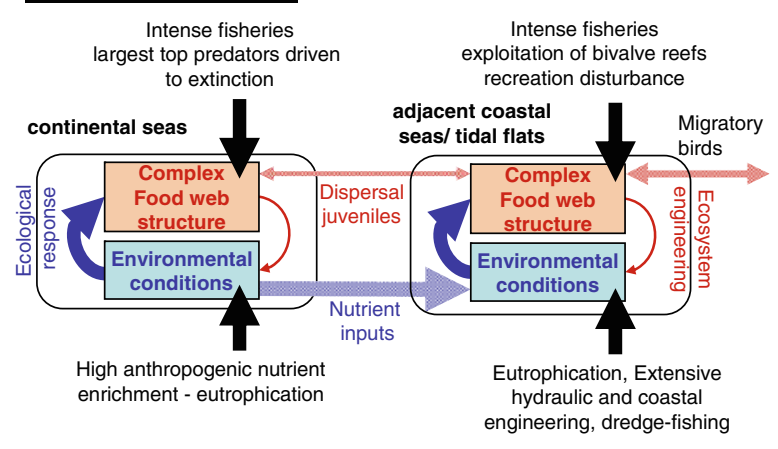

Figure 3. Changes in the relation between species and environmental factors in a meta-ecosystem context of a coastal system. A historic conditions: strong internal biotic feedback control of environmental conditions. B current situation: loss of internal biotic feedback, replacement by external forcing of human interventions in adjacent river and continental off-shore ecosystems.

disturbances change shallow soft-bottom communities from mainly internally regulated systems to systems dominated by external forcing (Figure 1C).

Before 1930, the supply of organic material from the North Sea to the Wadden Sea was one-third of the locally produced PP (Wolff and others 1979). Wolff and others (1979) estimated that the supply of organic material from off-shore in the 1970s was twice that of the local production. This indicates that before the reclamation in 1932, the system had significant internal regulation of both pelagic and benthic production by seagrass meadows and blue mussel beds, and a low impact of external nutrient resources. From the 1970s onward, the Wadden Sea became a system that imports a lot of nutrients from the North Sea (van Beusekom and de Jonge 2002), and PP is dominated by microalgae whose growth rates respond much faster to increased resource conditions than perennial macrophytes (Cloern 2001). Accordingly, the system responded strongly to external nutrient loads during the 1980s (Figure 2A, B). After 1990 the internal contribution of sediment stabilizing ecosystem engineers (that were fished away) to both the benthic and pelagic PP decreased dramatically in the western Wadden Sea. Thus, the documented gradual decline in pelagic production over the last decade may depend both on declining external nutrient loads, a continuous decrease in Secchi depth, and/or the loss of blue mussel remineralization. This indicates a modern Wadden Sea with a low degree of internal and a high degree of external regulation. A good understanding of the dynamics between external and internal processes is critical for formulating an appropriate strategy for recovery of highly valuable coastal areas. The historical development of the Wadden Sea and marine systems in general, suggests that human-driven changes both in the internal regulation of local abiotic conditions and in the external forcing have made coastal systems increasingly governed by external processes (Figure 3).

\section{Discussion}

Our synthesis indicates that human-driven shifts in ecosystem organization have contributed strongly to change the Wadden Sea from a historical state dominated by internal regulation from sedimentstabilizing ecosystem engineers (seagrass meadows and mussel beds) to a modern state dominated by sediment destabilizing macrofauna (mainly polychaetes) and regulated by external drivers. The latter include high resource extraction and erosion from dredging and trawling, high inputs of offshore organic matter and nutrient inputs from the North Sea, and strong alteration of hydrodynamics from human engineering activities (Figure 4). Parallel changes in bird populations, including relative increases in species that mainly feed on marine worms compared to species that mainly feed on bivalves, indicate that the shift in macrozoobenthos communities has been channelled to higher trophic levels in the food-web (van Roomen and others 2005). Similar changes toward wormfeeding waterbirds in the Wash, England, have also been attributed to shellfishery induced declines in mussel beds (Atkinson and others 2010).

We can also distinguish four phases in the development of the western Wadden Sea (Figure 2). Phase I (1900-1930) is a period of low external nutrient loading with high water transparency, high pelagic production and a high contribution of subtidal seagrass (Zostera marina) to the benthic production. Phase II (1930-1970) is a period with still relatively low nutrient concentrations, decreasing transparency of the water with a parallel decrease in pelagic production, and an almost total loss of subtidal seagrass. Phase III (1970-1990) is a period of very high nutrient loads and a doubling of 

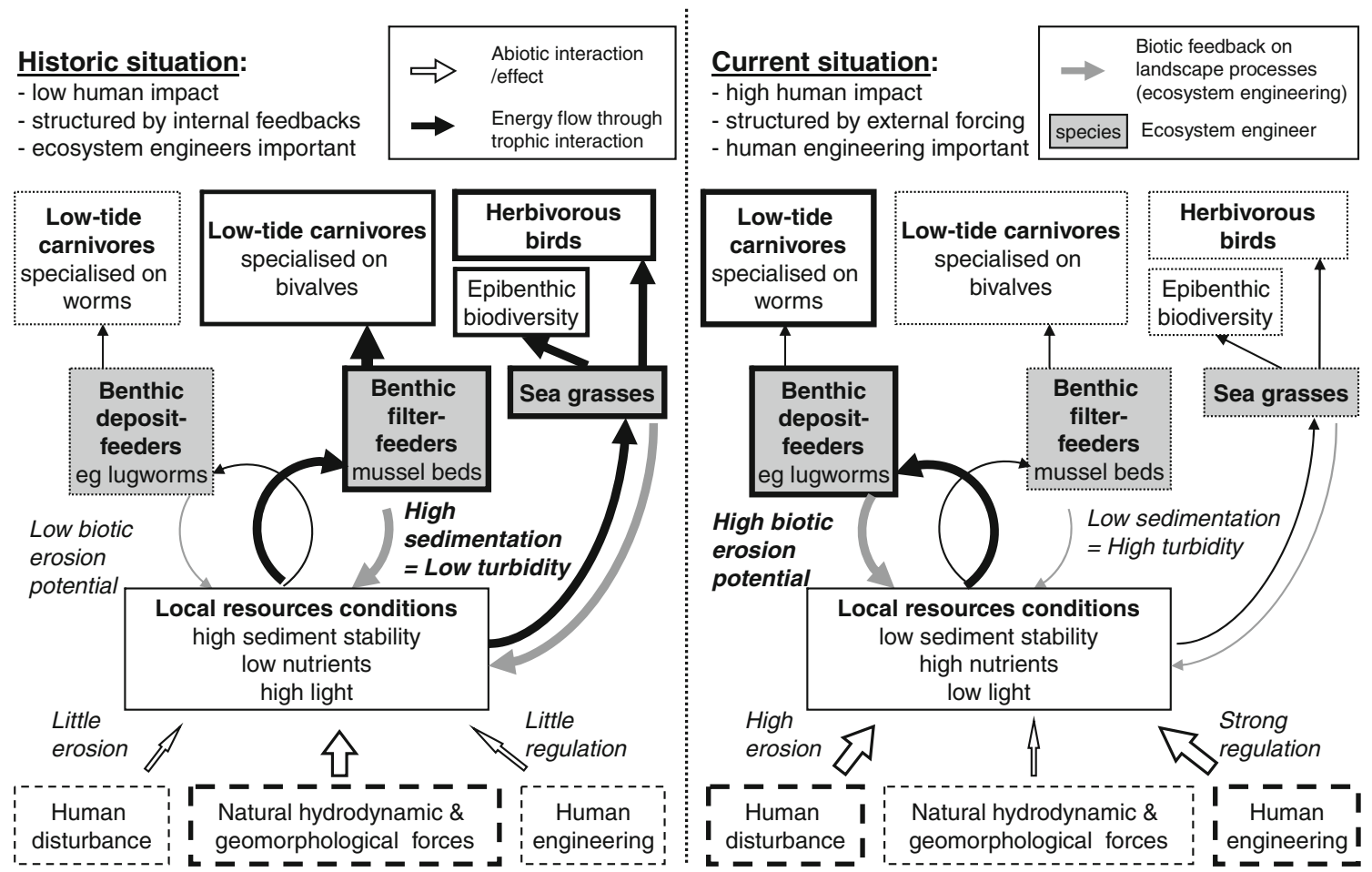

Figure 4. Human-induced changes in trophic structure and regulation of the Wadden Sea ecosystem, based on the presented hypotheses and trends presented in Figures 1, 2 and 3. Exploitation of benthic filter feeders together with high inputs of off-shore organic matter and nutrients from the North Sea, high erosion from dredging and trawling, and strong regulation of hydrodynamics from human engineering activities, may have changed the energy transfer in the food web from herbivorous and filter feeding pathways to a mainly detrivorous dominated pathway. The thickness of the frames of the boxes indicates relative density and abundance of the different species groups or intensity of the drivers.

pelagic production restoring levels to historical estimations. There is a continuing decrease of water transparency and no significant recovery of subtidal seagrass. During this phase shellfish fisheries expand and intensify. Phase IV (1990-2008) is a period of gradually declining nutrient concentrations, water transparency and pelagic production, whereas dramatic decreases in intertidal mussel beds are paralleled by increases in polychaete worms. The distinctly different relations between species groups in the different phases show that the system has not responded linearly to external forcing: there are periods with equally high pelagic production under both low and high nutrient loads (phase I and III), and there are periods with distinctly different compositions of benthic production under similar nutrient loads (phase II and IV, Figure 2). Thus, our results indicate complex dynamics, where the different time periods in the Wadden Sea have different relations between external abiotic conditions and biological production. This contrasts strongly with the traditional management view of coastal ecosystems in which production mainly is driven by linear and reversible responses to resource load, and specifically to recent concerns that it is modern water quality management that is most responsible for decreased production of fisheries resources (Daan and van der Mheen 2004; Philippart and others 2007). Instead, our synthesis indicates that the western Wadden Sea system may have lost much of its internal contribution to production by human disturbances, which makes the modern state highly vulnerable to external nutrient loads.

The strong feedbacks described between benthic ecosystem engineers and sediment conditions may have fundamental consequences for the resilience and recovery potential of these habitats. Systems structured by biological feedbacks are sensitive to non-linear dynamics in response to changing environmental variables. If feedbacks are strong enough, theory suggests that it could lead to alternative stable states where biological engineering may enable communities dominated by different groups of species with different functional properties, to exist under the same external conditions (Scheffer and others 2001; Van De Koppel and others 2001; Rietkerk and others 2004; van de Koppel and others 2005b). When an ecosystem 
with alternative stable states is exposed to gradually changing environmental conditions, it may at first seem highly resilient to change, because changes are buffered by the internal feedback. However, at some point, a critical threshold may be crossed beyond which buffering is no longer possible, causing the system to collapse to an alternative stable state. This may in turn reverberate back on higher trophic levels as a change both in physical conditions and the type of dominant food-base, generating an ecosystem level change-a regime shift - to a state dominated by external drivers or other biological feedbacks (Folke and others 2004). If there has indeed been such a shift in the Wadden Sea, this suggests that we may need to improve conditions beyond the initial point of collapse of seagrass meadows and mussel beds to restore the system, because of new feedbacks that may favor the alternative community (a phenomenon called hysteresis, Figure 5). The importance of acknowledging such non-linear dynamics and ecosystem engineering feedbacks was clearly demonstrated in a recent large scale-35 ha-oyster restoration project in Virginia, where restoration only was successful if the restored reef structure initially was large enough to have significant effects on hydrodynamics (Schulte and others 2009).

The lack of recovery of both subtidal seagrasses and intertidal blue mussels after the disturbance events does indeed indicate that human activities have changed the abiotic conditions and/or deleted feedbacks from the biological communities neces-

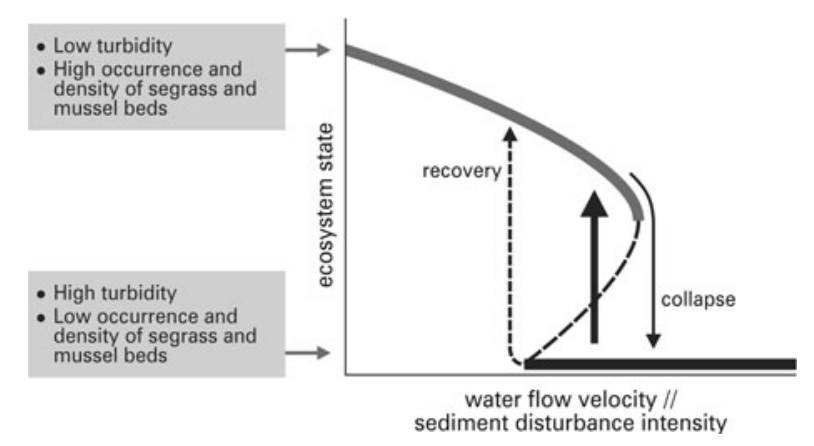

Figure 5. Alternative stable states in soft-sediment habitats depending on interactions between ecosystem engineers reducing water flow and stabilizing the sediment (seagrass meadows or reef building species) and external drivers of sediment stability. Grey and black lines show the ecosystem states with (grey) and without (black) dominance of sediment stabilizing ecosystem engineers, such as seagrass or reef building bivalves. Thin arrows show changes between the ecosystem states due to externally induced changes in sediment conditions. Thick arrow shows a possible shift between the ecosystem states at similar external conditions. sary for reestablishment. For seagrass there is compelling evidence that subtidal seagrass recovery at present is impossible because of increased amounts of suspended sediments in the water, limiting light availability (van der Heide and others 2007). The increase of suspended sediments in the water column is partly a consequence of the reduction in subtidal seagrass itself and partly of the changed hydrodynamics due to large-scale coastal protection measures, such as dams, dikes and goynes (van der Heide and others 2007). Based on the trends and processes we have described, we propose that a human-driven regime shift in trophic structures and ecosystem regulation has moved the Wadden Sea from an internally regulated system dominated by sediment stabilizing ecosystem engineers, towards a system driven by external drivers and dominated by sediment destabilizing deposit feeders. If the apparent nonlinearity of soft-bottom systems is true, it may be difficult to restore the degraded habitats and production potential of the system without more radical measures than just the reduction of local human impacts, which is the dominating strategy by nature management, conservation organizations and policy makers today. Our synthesis suggests: (1) that we need to adopt an ecosystem-based management perspective that acknowledges the strong and dynamic interdependencies between nature conservation, fisheries, water quality management and coastal defence, and (2) that restoration projects of seagrass meadows and bivalve reefs need to be performed at such scales that we also restore the important feedback mechanisms needed to promote those local abiotic conditions that are favorable for the target species (see also: van der Heide and others 2007; Eriksson and others 2009; Schulte and others 2009).

\section{ACKNOWLEDGEMENTS}

We thank Serena Donadi, Johan Eklöv and Els van der Zee for stimulating discussions, Dick Visser for artwork, and Heike Lotze, Simon Thrush and an anonymous reviewer for valuable comments on the text.

\section{OPEN ACCESS}

This article is distributed under the terms of the Creative Commons Attribution Noncommercial License which permits any noncommercial use, distribution, and reproduction in any medium, provided the original author(s) and source are credited. 


\section{REFERENCES}

Airoldi L, Beck MW. 2007. Loss, status and trends for coastal marine habitats of Europe. Oceanogr Mar Biol 45:345-405.

Armonies W, Herre E, Sturm M. 2001. Effects of the severe winter 1995/96 on the benthic macrofauna of the Wadden Sea and the coastal North Sea near the island of Sylt. Helgoland Mar Res 55:170-5.

Asmus RM, Asmus H. 1991. Mussel beds-limiting or promoting phytoplankton. J Exp Mar Biol Ecol 148:215-32.

Asmus H, Asmus R. 2000. Material exchange and food web of seagrass beds in the Sylt-Romo Bight: how significant are community changes at the ecosystem level? Helgoland Mar Res 54:137-50.

Atkinson PW, Maclean IMD, Clark NA. 2010. Impacts of shellfisheries and nutrient inputs on waterbird communities in the Wash, England. J Appl Ecol 47:191-9.

Baird D, Asmus H, Asmus R. 2007. Trophic dynamics of eight intertidal communities of the Sylt-Romo Bight ecosystem, northern Wadden Sea. Mar Ecol Prog Ser 351:25-41.

Beukema JJ, Cadee GC. 1996. Consequences of the sudden removal of nearly all mussels and cockles from the Dutch Wadden Sea. Mar Ecol 17:279-89.

Bouma TJ, Olenin S, Reise K, Ysebaert T. 2009. Ecosystem engineering and biodiversity in coastal sediments: posing hypotheses. Helgoland Mar Res 63:95-106.

Burkholder JM, Tomasko DA, Touchette BW. 2007. Seagrasses and eutrophication. J Exp Mar Biol Ecol 350:46-72.

Cadee CG. 1980. Reappraisal of the production and import of organic carbon in the western Wadden Sea. Neth J Sea Res 14:305-22.

Cadee CG, Hegeman J. 1974. Primary production of phytoplankton in the Dutch Wadden Sea. Neth J Sea Res 8:24059.

Churchill JH. 1989. The effect of commercial trawling on sediment resuspension and transport over the middle Atlantic bight continental-shelf. Cont Shelf Res 9:841-64.

Cloern JE. 2001. Our evolving conceptual model of the coastal eutrophication problem. Mar Ecol Prog Ser 210:223-53.

Colijn F, Cadee GC. 2003. Is phytoplankton growth in the Wadden Sea light or nitrogen limited? J Sea Res 49:83-93.

Costanza R, dArge R, deGroot R, Farber S, Grasso M, Hannon B, Limburg K, Naeem S, Oneill RV, Paruelo J, Raskin RG, Sutton P, vandenBelt M. 1997. The value of the world's ecosystem services and natural capital. Nature 387:253-60.

Daan N, van der Mheen HW. 2004. Outstanding environmental issues in relation to European fisheries. Neth Inst Fish Res RIVO 62:1-21.

Dankers NMJA, Meijboom A, Cremer JSM, Dijkman EM, Hermes Y, te Marvelde L. 2003. Historische ontwikkeling van droogfallende mosselbanken in de Nederlandse Wadden Zee. Alterra Rep 873:1-114.

Daskalov GM, Grishin AN, Rodionov S, Mihneva V. 2007. Trophic cascades triggered by overfishing reveal possible mechanisms of ecosystem regime shifts. Proc Natl Acad Sci USA 104:10518-23.

de Boer WF. 2007. Seagrass-sediment interactions, positive feedbacks and critical thresholds for occurrence: a review. Hydrobiologia 591:5-24.

De Jonge VN, Essink K, Boddeke R. 1993. The Dutch Wadden Sea-a changed ecosystem. Hydrobiologia 265:45-71.
Dijkema KS. 1997. Molluscan fisheries and culture in the Netherlands U.S. Commer., NOAA Tech. Rep. NMFS 129:11535.

Duarte CM. 2002. The future of seagrass meadows. Environ Conserv 29:192-206.

Erftemeijer PLA, Lewis RRR. 2006. Environmental impacts of dredging on seagrasses: a review. Mar Pollut Bull 52:1553-72.

Eriksson BK, Rubach A, Hillebrand H. 2006. Biotic habitat complexity controls species diversity and nutrient effects on net biomass production. Ecology 87:246-54.

Eriksson BK, Ljunggren L, Sandström A, Johansson G, Mattila J, Rubach A, Råberg S, Snickars M. 2009. Declines in predatory fish promote bloom-forming macroalgae. Ecol Appl 19:197588.

Essink K. 2005. Macrozoobenthos. Wadden Sea Ecosyst 19:184-9.

Estes JA, Tinker MT, Williams TM, Doak DF. 1998. Killer whale predation on sea otters linking oceanic and nearshore ecosystems. Science 282:473-6.

Flach EC. 1992. Disturbance of benthic infauna by sedimentreworking activities of the lugworm Arenicola marina. Neth $J$ Sea Res 30:81-9.

Folke C, Carpenter S, Walker B, Scheffer M, Elmqvist T, Gunderson L, Holling CS. 2004. Regime shifts, resilience, and biodiversity in ecosystem management. Annu Rev Ecol Evol Syst 35:557-81.

Giesen W, Vankatwijk MM, Denhartog C. 1990. Eelgrass condition and turbidity in the Dutch Wadden Sea. Aquatic Bot $37: 71-85$.

Gunderson LH. 2001. Managing surprising ecosystems in southern Florida. Ecol Econ 37:371-8.

Gutierrez JL, Jones CG, Strayer DL, Iribarne OO. 2003. Mollusks as ecosystem engineers: the role of shell production in aquatic habitats. Oikos 101:79-90.

Hall SJ. 1994. Physical disturbance of marine benthic communities-life in unconsolidated sediments. Oceanogr Mar Biol 32:132-79.

Harley CDG, Hughes AR, Hultgren KM, Miner BG, Sorte CJB, Thornber CS, Rodriguez LF, Tomanek L, Williams SL. 2006. The impacts of climate change in coastal marine systems. Ecol Lett 9:228-41.

Hemminga MA, Duarte CM. 2000. Seagrass ecology. Cambridge: Cambridge University Press.

Hughes RG, Lloyd D, Ball L, Emson D. 2000. The effects of the polychaete Nereis diversicolor on the distribution and transplanting success of Zostera noltii. Helgoland Mar Res 54:12936.

Huxham M, Gilpin L, Mocogni M, Harper S. 2006. Microalgae, macrofauna and sediment stability: an experimental test of a reciprocal relationship. Mar Ecol Prog Ser 310:55-63.

Jackson JBC, Kirby MX, Berger WH, Bjorndal KA, Botsford LW, Bourque BJ, Bradbury RH, Cooke R, Erlandson J, Estes JA, Hughes TP, Kidwell S, Lange CB, Lenihan HS, Pandolfi JM, Steneck PCHRS, Tegner MJ, Warner RR. 2001. Historical overfishing and the recent collapse of coastal ecosystems. Science 293:629-38.

Jones CG, Lawton JH, Shachak M. 1994. Organisms as ecosystem engineers. Oikos 69:373-86.

Kesteloo JJ, Stralen MR, Breen V, Craeymeersch JA. 2004. Het kokkelbestand in de Nederlandse kustwateren in 2004. Nederlands Instituut voor Visserij onderzoek (RIVO) BV Rapport C052:1-48. 
Langton RW, Robinson WE. 1990. Faunal associations on scallop grounds in the Western Gulf of Maine. J Exp Mar Biol Ecol 144:157-71.

Ljunggren L, Sandström A, Bergström U, Mattila J, Lappalainen A, Johansson G, Sundblad G, Casini M, Kaljuste O, Eriksson BK. Recruitment failure of coastal predatory fish in the Baltic Sea is related to an offshore system shift. ICES J Mar Sci (in press).

Lotze HK, Reise K. 2005. Ecological history of the Wadden Sea. Helgoland Mar Res 59:1.

Lotze HK, Reise K, Worm B, van Beusekom J, Busch M, Ehlers A, Heinrich D, Hoffmann RC, Holm P, Jensen C, Knottnerus OS, Langhanki N, Prummel W, Vollmer M, Wolff WJ. 2005. Human transformations of the Wadden Sea ecosystem through time: a synthesis. Helgoland Mar Res 59:84-95.

Lotze HK, Lenihan HS, Bourque BJ, Bradbury RH, Cooke RG, Kay MC, Kidwell SM, Kirby MX, Peterson CH, Jackson JBC. 2006. Depletion, degradation, and recovery potential of estuaries and coastal seas. Science 312:1806-9.

Menge BA. 2000. Top-down and bottom-up community regulation in marine rocky intertidal habitats. J Exp Mar Biol Ecol 250:257-89.

Montserrat F, Van Colen C, Degraer S, Ysebaert T, Herman PMJ. 2008. Benthic community-mediated sediment dynamics. Mar Ecol Prog Ser 372:43-59.

Olff H, Alonso DA, Berg MP, Eriksson BK, Loreau M, Piersma T, Rooney N. 2009. Parallel interaction webs in ecosystems. Philos Trans R Soc B 364:1755-79.

Orth RJ, Carruthers TJB, Dennison WC, Duarte CM, Fourqurean JW, Heck KL, Hughes AR, Kendrick GA, Kenworthy WJ, Olyarnik S, Short FT, Waycott M, Williams SL. 2006. A global crisis for seagrass ecosystems. Bioscience 56:987-96.

Österblom H, Hansson S, Hjerne O, Larsson U, Wulff F, Elmgren R, Folke C. 2007. Human-induced trophic cascades and ecological regime shifts in the Baltic Sea. Ecosystems 10:887-9.

Peterson CH, Summerson HC, Fegley SR. 1987. Ecological consequences of mechanical harvesting of clams. Fish Bull 85:281-98.

Pfister CA. 2007. Intertidal invertebrates locally enhance primary production. Ecology 88:1647-53.

Philippart CJM. 1994. Interactions between Arenicola marina and Zostera noltii on a tidal flat in the Wadden Sea. Mar Ecol Prog Ser 111:251-7.

Philippart CJM, Cadee GC. 2000. Was total primary production in the western Wadden Sea stimulated by nitrogen loading? Helgoland Mar Res 54:55-62.

Philippart CJM, Beukema JJ, Cadee GC, Dekker R, Goedhart PW, van Iperen JM, Leopold MF, Herman PMJ. 2007. Impacts of nutrient reduction on coastal communities. Ecosystems 10:95-118.

Piersma T, Koolhaas A, Dekinga A, Beukema JJ, Dekker R, Essink K. 2001. Long-term indirect effects of mechanical cockledredging on intertidal bivalve stocks in the Wadden Sea. J Appl Ecol 38:976-90.

Postma H. 1954. Hydrography of the Dutch Wadden Sea. Arch Neerl Zool 10:405-511.

Reise K. 1985. Tidal flat ecology: an experimental approach to species interactions. Berlin: Springer-Verlag.

Rhoads DC. 1974. Organism-sediment relation on the muddy sea floor. Oceanogr Mar Biol Annu Rev 12:263-300.
Rhoads DC, Young DK. 1970. Influence of deposit-feeding organisms on sediment stability and community trophic structure. J Mar Res 28:150.

Riemann B, Hoffmann E. 1991. Ecological consequences of dredging and bottom trawling in the Limfjord, Denmark. Mar Ecol Prog Ser 69:171-8.

Rietkerk M, Dekker SC, de Ruiter PC, van de Koppel J. 2004. Self-organized patchiness and catastrophic shifts in ecosystems. Science 305:1926-9.

Schaffner LC, Dellapenna TM, Hinchey EK, Friedrichs CT, Neubauer MT, Smith ME, Kuehl SA. 2001. Physical energy regimes, seabed dynamics and organism-sediment interactions along an estuarine gradient. In: Aller JY, Woodin SA, Aller RC, Eds. Organism-sediment interactions. Columbia: University of South Carolina Press.

Scheffer M, Carpenter S, Foley JA, Folke C, Walker B. 2001. Catastrophic shifts in ecosystems. Nature 413:591-6.

Schulte DM, Burke RP, Lipcius RN. 2009. Unprecedented restoration of a native oyster metapopulation. Science 325:11248 .

Shepherd PCF, Boates JS. 1999. Effects of a commercial baitworm harvest on semipalmated sandpipers and their prey in the Bay of Fundy hemispheric shorebird reserve. Conserv Biol $13: 347-56$.

Siebert T, Branch GM. 2006. Ecosystem engineers: interactions between eelgrass Zostera capensis and the sandprawn Callianassa kraussi and their indirect effects on the mudprawn Upogebia africana. J Exp Mar Biol Ecol 338:253-70.

Terrados J, Duarte CM. 2000. Experimental evidence of reduced particle resuspension within a seagrass (Posidonia oceanica L.) meadow. J Exp Mar Biol Ecol 243:45-53.

Valiela I, Bowen JL, York JK. 2001. Mangrove forests: one of the world's threatened major tropical environments. Bioscience 51:807-15.

van Beusekom JEE. 2005. A historic perspective on Wadden Sea eutrophication. Helgoland Mar Res 59:45-54.

van Beusekom JEE, de Jonge VN. 2002. Long-term changes in Wadden Sea nutrient cycles: importance of organic matter import from the North Sea. Hydrobiologia 475:185-94.

Van Colen C, Montserrat F, Verbist K, Vincx M, Steyaert M, Vanaverbeke J, Herman PMJ, Degraer S, Ysebaert T. 2009. Tidal flat nematode responses to hypoxia and subsequent macrofauna-mediated alterations of sediment properties. Mar Ecol Prog Ser 381:189-97.

Van De Koppel J, Herman PMJ, Thoolen P, Heip CHR. 2001. Do alternate stable states occur in natural ecosystems? Evidence from a tidal flat. Ecology 82:3449-61.

van de Koppel J, Rietkerk M, Dankers N, Herman PMJ. 2005a. Scale-dependent feedback and regular spatial patterns in young mussel beds. Am Nat 165:66-77.

van de Koppel J, van der Wal D, Bakker JP, Herman PMJ. 2005b. Self-organization and vegetation collapse in salt marsh ecosystems. Am Nat 165:E1-12.

van der Heide T, van Nes EH, Geerling GW, Smolders AJP, Bouma TJ, van Katwijk MM. 2007. Positive feedbacks in seagrass ecosystems: implications for success in conservation and restoration. Ecosystems 10:1311-22.

van Gils JA, Kraan C, Dekinga A, Koolhaas A, Drent J, de Goeij P, Piersma T. 2009. Reversed optimality and predictive ecology: burrowing depth forecasts population change in a bivalve. Biol Lett 5:5-8. 
van Nes EH, Amaro T, Scheffer M, Duineveld GCA. 2007. Possible mechanisms for a marine benthic regime shift in the North Sea. Mar Ecol Prog Ser 330:39-47.

van Raaphorst W, de Jonge VN. 2004. Reconstruction of the total $\mathrm{N}$ and $\mathrm{P}$ inputs from the Ijsselmeer into the western Wadden Sea between 1935-1998. J Sea Res 51:109-31.

van Roomen M, van Turnhout C, van Winden E, Koks B, Goedhart P, Leopold M, Smit C. 2005. Trends in benthivorous waterbirds in the Dutch Wadden Sea 1975-2002: large differences between shellfish-eaters and worm-eaters. Limosa 78:21-38.

Verwey J. 1952. On the ecology of distribution of cockle and mussel in the Dutch waddensea, their role in sedimentation and the source of their food supply, with a short review of the feeding behaviour of bivalve mollusks. Arch Néerl Zool 10:171-239.

Vitousek PM, Mooney HA, Lubchenco J, Melillo JM. 1997. Human domination of earth's ecosystems. Science 277:494-9.

Ward LG, Kemp WM, Boynton WR. 1984. The influence of waves and seagrass communities on suspended particles in an estuarine embayment. Mar Geol 59:85-103.
Weijerman M, Lindeboom H, Zuur AF. 2005. Regime shifts in marine ecosystems of the North Sea and Wadden Sea. Mar Ecol Prog Ser 298:21-39.

Wolff WJ. 2000. Causes of extirpations in the Wadden Sea, an estuarine area in the Netherlands. Conserv Biol 14:876-85.

Wolff WJ. 2005. The exploitation of living resources in the Dutch Wadden Sea: a historical overview. Helgoland Mar Res 59:31-8.

Wolff WJ, den Hartog C, Dijkema KS, Admiraal W, Colijn F, van den Hoek C, Joenje W, de Jonge VN, Polderman PJG. 1979. Flora and vegetation of the Wadden Sea. Report of the Wadden Sea Working Group 3:1-206.

Worm B, Lotze HK, Hillebrand H, Sommer U. 2002. Consumer versus resource control of species diversity and ecosystem functioning. Nature 417:848-51.

Worm B, Barbier EB, Beaumont N, Duffy JE, Folke C, Halpern BS, Jackson JBC, Lotze HK, Micheli F, Palumbi SR, Sala E, Selkoe KA, Stachowicz JJ, Watson R. 2006. Impacts of biodiversity loss on ocean ecosystem services. Science 314:78790. 